\title{
ANALISIS KESULITAN DAN STRATEGI GURU DALAM MELAKSANAKAN PENILAIAN PEMBELAJARAN PADA MASA COVID-19 DI SEKOLAH DASAR
}

\author{
Ana Nurhasanah ${ }^{1}$, Reksa Adya Pribadi ${ }^{2}$, Nur Salsabila Rahayu ${ }^{3}$ \\ 1,2,3PGSD FKIP Universitas Sultan Ageng Tirtayasa \\ 1ananur74@untirta.ac.id, 2reksapribadi@untirta.ac.id2, \\ 32227190003@untirta.ac.id
}

\begin{abstract}
The purpose of this research is to find out the difficulties and strategies of teachers in carrying out learning assessments during the Covid-19 period in elementary schools. The type of research conducted is descriptive qualitative where research that describes the research subject qualitatively means that the data collected are in the form of words or pictures. This research was conducted in one of the elementary schools in Tanggerang district, namely SDN Renged 3. From the results of the study the difficulties of teachers in carrying out assessments during the COVID-19 pandemic, namely the limitations of face-to-face learning, conducting affective and psychomotor assessments and finally the limitations of students in participating in learning activities. online learning (in the network). And the strategy used by the teacher in carrying out the assessment is by giving assignments, holding face-to-face learning in turns and from the craft of students.
\end{abstract}

Keywords: Difficulty, Strategy, Assessment.

\begin{abstract}
ABSTRAK
Tujuan dari dilakukannya penelitian ini yaitu untuk mengetahui kesulitan dan strategi guru dalam melaksanakan penilaian pembelajaran pada masa covid-19 di sekolah dasar. Jenis penelitian yang dilakukan yaitu deskriftif kualitatif dimana penelitian yang menggambarkan subjek penelitian secara kualitatif artinya yang dikumpulkan berupa kata-kata ataupun gambaran-gambaran. Penelitian ini dilakukan di salah satu sekolah dasar yang terdapat di kabupaten Tanggerang yaitu SDN Renged 3. Dari hasil penelitian kesulitan guru dalam melaksanakan penilaian selama pandemic covid-19 yaitu keterbatasan pembelajaran tatap muka, melakukan penilaian afektif dan psikomotorik dan yang terakhir keterbatasan peserta didik dalam mengikuti pembelajaran daring (dalam jaringan). Dan strategi yang dilakukan guru dalam melaksanakan penilaian yaitu dengan memberikan tugas, mengadakan pembelajaran tatap muka secara bergilir dan dari kerajinan peserta didik .
\end{abstract}

Kata kunci: Kesulitan, Strategi, Penilaian. 


\section{A. Pendahuluan}

Penilaian pembelajaran merupakan proses yang dilakukan guru dalam mengumpulkan data dari hasil kegiatan pembelajaran yang sebelumnya telah dilakukan oleh peserta didik, penilaian pembelajaran dilakukan dari tiga aspek yaitu kognitif yang berkaitan dengan pengetauan peserta didik, afektif yang berkaitan dengan sikap peserta didik dan psikomotorik yang berkaitan dengan keterampilan peserta didik. Penilaian pembelajaran yang diarahkan oleh kurikulum 13 yaitu penilaian autentik yaitu yang memperhatikan hasil belajar peserta didik untuk ranah pengetahuan, sikap dan keterampilan.

Pebelajaran merupakan proses peserta didik dalam belajar dan mendapatkan informasi serta pengalaman. Akan tetapi disaat seperti ini dimana sedang terjadi penyebaran covid-19 diberbagai Negara salah satunya Indonesia, tidak memungkinkan bagi sekolah untuk melakukan pembelajaran secara tatap muka, sehingga pemerintah mengeluarkan kebijakan untuk melakukan pembelajaran secara daring (dalam jaringan) agar meminimalisir terjadinya penyebaran virus covid-19. Hal tersebut berdampak pada pembelajara di sekolah, banyak hal yang harus guru dan peserta didik persiapkan dalam menghadapi pembelajaran daring, karna pembelajaran daring merupakan hal baru yang.

\section{Pembelajaran} daring merupakan inovasi yang gunakan dalam menghadapi wabah covid-19 dalam dunia pendidikan, karena kegiatan belajar mengajar harus tetap berjalan. Pembelajaran daring merupakan kegiatan pembelajaran yang memanfaatkan jaringan internet, serta teknologi pendukung lain seperti handphone, laptop dan lain sebaginya sebagai penunjang dalam kegiatan pembelajaran.

Guru merupakan pendidik yang profesional dengan tugas utama mendidik, mengajar, membimbing, mengarahkan, melatih, menilai, dan mengevaluasi peserta didik pada pendidikan anak usia dini jalur pendidikan formal, pendidikan dasar, dan menengah (Kamiludin \& Suryaman, 2017). Dalam melakukan tugas-tugas tersebut pasti guru memiliki kesulitan salah satunya dalam melakukan penilaian apalagi 
dimasa covid-19 pembelajara dilakukan dengan daring (dalam jaringan) dimana guru dan peserta didik tidak dapat bertatap muka langsung dan hanya melakukan pembelajaran melalui google meet, zoom meet, google form dan lain sebaginya, hal tersebut membuat guru terbatas dalam melakukan penilaian. Dengan begitu untuk menghadapi kesulitan yang terjadi karena pembelajaran dilaksanakan secara daring maka guru harus memiliki strategi untuk melakukan penilaian.

Strategi merupakan usaha yang dilakukan didalam merancang pembelajaran untuk mencapai tujuan yang telah ditetapkan (Syahrial et al., 2019). Senada dengan pendapat tersebut, strategi merupakan perencanaan, langkah-langkah dan suatu rangkaian untuk mencapai tujuan pembelajaran (Yamin, 2013, p. 1). Oleh karena itu setiap guru dalam melaksanakan pembelajaran dan penilaian memerlukan strategi agar dapat mencapai tujuan pembelajaran yang telah direncakanakan.

Dalam dunia pendidikan strategi merupakan perencanaan yang berisikan tentang rangkaian kegiatan yang dibuat untuk membantu dalam mencapai tujuan pendidikan tertentu. Dalam kegiatan penilaian, seorang guru dituntut untuk selalu mengembangkan potensi dirinya agar dapat menelaah strategi yang tepat untuk digunakan dalam penilaian, karena pada kondisi sekarang yaitu pembelajaran dilakukan secara daring guru harus memiliki strategi dalam melaksanakan penilaian karena tidak adanya interaksi secara langsung antara guru dan peserta didik. Seorang guru tidak dapat mengandalkan stategi yang sama dalam melaksanakan penilaian pada waktu sebelum pandemi yang mana pembelajaran terjadi secara tatap muka, tetapi guru harus memiliki strategi penilaian yang tepat untuk menghadapi pembelajaran daring dan guru mampu mengetahui sejauh mana pengetahuan siswa terhadap mata pelajaran yang telah diajarkan.

Penilaan merupakan hal yang penting dalam kegiatan pembelajaran, karena dengan dilakukannya penilaian guru dapat mengetahui sejauh mana pemahaman peserta didik terhadap materi yang telah dipelajari, selain itu juga dengan dilakukannya peilaian 
bisa dijadikan sebagai perbaikan guru dalam melakukan kegiatan pembelajaran yang akan datang. Kementerian Pendidikan Dan Kebudayaan (Pedoman Penilaian di Sekolah Dasar. 2013:4-5) mengemukakan bahwa penilaian dalam Kurikulum 2013 memiliki beberapa karakteristik, yaitu belajar tuntas, otentik, berkesinambungan, menggunakan teknik penilaian yang bervariasi dan berdasarkan acuan kriteria. Dalam penilaian perlu diperhatikan bahwa dalam melakuakan penilaian guru harus memenuhi krakteristik penilaian kurikuluk 13.

Kementerian Pendidikan Dan Kebudayaan (Pedoman Penilaian di Sekolah Dasar. 2013:7) mengungkapkan bahwa, "penilaian di SD dilakukan dalam berbagai teknik untuk semua kompetensi dasar yang dikategorikan dalam tiga aspek, yaitu sikap, pengetahuan, dan keterampilan". Oleh karena itu untuk menemukan hasil penilaian dari ketiga aspek tersebut diperlukan strategi penilaian yang harus dilakukan oleh guru apalagi disituasi pembelajaran daring.
Berdasarkan

permasalahan yang telah diuraikan maka penelitian ini bertujuan untuk mendeskripsikan kesulitan dan strategi guru dalam melaksanakan penilaian pembelajaran pada masa covid-19 di sekolah dasar

\section{B. Metode}

Jenis pada penelitian ini yaitu deskriptif kualitatif dimana penelitian yang menggambarkan subjek penelitian secara kualitatif artinya yang dikumpulkan berupa kata-kata ataupun gambaran-gambaran. Maka peneliti akan mengkaji secara mendalam sesuai judul yaitu tentang analisis kesulitan dan strategi guru dalam melaksanakan penilaian pembelajaran pada masa covid-19 di sekolah dasar. Dengan dilakukannya penelitian ini peneliti memiliki tujuan yaitu untuk mengetahui kesulitan dan strategi guru dalam melaksanakan penilaian pembelajaran pada masa covid-19 di sekolah dasar dasar yang dilakukan di SDN Renged 3. Pada penelitian ini instrument utaya yaitu peneliti itu sendiri. Data dalam penelitian berupa data sekolah SDN Renged 3 dan data hasil wawancara dengan subjek penelitian. Sedangkan 
subjek penelitian ini adalah guru kelas rendah SDN Renged 3.

$\begin{array}{ccc}\text { Teknik pengumpulan data } \\ \text { dilakukan } & \text { dengan } & \text { cara }\end{array}$
mewawancarai guru SDN Renged 3 kelas rendah. Langkah pertama yang dilkukan dalam pengumpulan data yaitu menganalisi data-data terkait permasalahan yang telah terkumpul. Peneliti menggunakan model analisis data interaksi. Data yang diperoleh dari hasil penelitian yang masih bersifat rumit akan direduksi, Menurut Sugiyono (2016: 247), reduksi data adalah merangkum, memilih hal-hal yang pokok, memfokuskan pada halhal yang penting, dicari tema dan polanya, pada akhirnya memberikan gambaran yang lebih jelas dan mempermudah untuk melakukan pengumpulan data selanjutnya. Hasil radi reduksi data tersebut kemudian disimpulkan dan dibuat rangkuman. Data yang telah dirangkum kemudian dilakukan penyeleksian data yang lebih khusus sesuai dengan yang dibutuhkan untuk penulisan data penelitian. Langkah terakhir yaitu penarikan kesimpulan dan verifikasi. Kesimpulan ini akan diikuti bukti-bukti yang diperoleh ketika penelitian dilapangan. Verifikasi data yang dimaksudkan untuk penentuan data akhir dari keseluruhan proses tahapan analisi, sehingga keseluruhan permasalahan mengenai kesulitan dan strategi guru dalam melaksanakan penilaian pembelajaran pada masa covid-19 di sekolah dasar

\section{Hasil dan Pembahasan}

1. Kesulitan Guru dalam Melaksanakan Pembelajaran Penilaian pada Masa Covid-19

Dari hasil wawancara yang telah peneliti lakukan di SDN Renged 3 bahwa secara keseluruan kesulitan yang dialami dalam melaksanakan penilaian pembelajaran selama masa covid-19 yaitu karna keterbatasan dalam melakukan pembelajaran tatap muka, hal tersebut membuat guru kesulitan dalam melakukan penilaian apalagi pada aspek afektif dan psikomotorik.

Hasil penelitian ini diperkuat dengan ungkapan dari salah satu guru SDN Renged 3 yang mengatakan bahwa:

"kesulitan dalam melakukan penilaian selama masa pandemic covid-19 itu karena keterbatasan dalam pembelajaran tatap muka, hal 
tersebut membuat guru sulit dalam melakukan penilaian afektif dan psikomotorik, bahkan untuk aspek kognitif pun sebenarnya mungkin ada beberapa dari peserta didik yang tugasnya dikerjakan oleh orang tunya. Bukan hanya itu dalam pengumpulan tugas pun ada yang tidak mengumpulkan dengan alasan tidak tahu ada tugas karena tidak memiliki handphone".

Berikut penjelasan kesulitan guru dalam melaksanakan penilaian pada masa covid-19:

a. Keterbatasan pembelajaran tatap muka

Selama masa pandemic covid-19 pembelajaran tatap muka dibatasi untuk mengurangi peyebaran virus covid-19, hal tersebut mengakibatkan guru tidak dapat secara langsung memberikan materi pembelajaran pada peserta didik dan guru juga tidak bisa melihat secara langsung proses belajar peserta didik yang dapat menjadi salah satu acuan penilaian pembelajaran. b. Kesulitan dalam melakukan penilaian afektif dan psikomotorik

Pada dasarnya penilaian kurikulum 13 mengacu pada penilaian kognitif, afektif dan psikomotorik, akan tetapi pada masa pandemic covid-19 pembelajaran secara tatap muka dibatasi, hal tersebut membuat guru kesulitan dalam melakukan penilaian afektif dan psikomotorik karena guru tidak bisa melihat langsung proses belajar setiap peserta didik.

Sejalan dengan kementerian Pendidikan Dan Kebudayaan (Pedoman Penilaian di Sekolah Dasar. 2013:7) mengungkapkan bahwa, "penilaian di SD dilakukan dalam berbagai teknik untuk semua kompetensi dasar yang dikategorikan dalam tiga aspek, yaitu sikap, pengetahuan, dan keterampilan".

c. Keterbatasan peserta didik dalam mengikuti 
pembelajaran

daring

(dalam jaringan)

Kondisi peserta didik yang berbeda-beda juga menjadi salah satu kesulitan guru dalam melakukan penilaian, karena ada beberapa murid yang tidak memiliki handphone dan jika memakai handphone orang tunaya hanya diwaktuwaktu tertentu karena orang tua peserta didik yang kerja, hal tersebut membuat guru kesulitan melakukan penilaian karena tugas dikirim melalui whatsapp grup akan tetapi ada peserta didik yang tidak mengerjakan dikarenakan tidak tau jika diberikan orang tua. Kendala tersebut membuat guru bingung dalam memberikan nilai karena penilaian hanya dari tugastugas yag diberika oleh guru.

2. Strategi Guru dalam Melaksanakan Penilaian Pembelajaran pada Masa Covid-19

a. Penilaian dilakukan dari hasil tugas yang diberikan
Dari hasil wawancara yang telah peneliti lakukan di SDN Renged 3 bahwa dalam menghadapi pembelajaran di sekolah dasar guru mengusahakan untuk memenuhi standar krakteristik penilaian kurikulum 13 yaitu tuntas, otentik, dan berkesinambungan.

Kementerian Pendidikan Dan Kebudayaan (Pedoman Penilaian di Sekolah Dasar. 2013:4-5) mengemukakan bahwa penilaian dalam Kurikulum 2013 memiliki beberapa karakteristik, yaitu belajar tuntas, otentik, berkesinambungan, menggunakan teknik penilaian yang bervariasi dan berdasarkan acuan kriteria. Walaupun pada kenyataanya ketiga karakteristik tersebut tidak terpenuhi selama pembelajaran daring yang dikarenakan keadaan keluarga dan lingkuan peserta didik yang kurang mendukung seperti ada peserta didik yang tidak memiliki handphone, kesulitan kuota dan lain sebagainya. Akan tetapi guru 
mencari jalan agar penilaian tetap terpenuhi dengan memberikan tugas-tugas kepada peserta didik, dari memberikan tugas tersebut guru dapat mengambil dari berbagai aspek seperti untuk kognitif guru mengambil dari nilai hasil tugas yang dikerjakan peserta didik, untuk psikomotorik guru dapat meliha dari tugas-tugas keterampilan yang diberikan, dan untuk afektif guru dapat meliat dari kerajinan peserta didik dalam mengerjakn tugas yag telah diberikan.

Hasil penelitian ini diperkuat dengan ungkapan dari salah satu guru SDN Renged 3 yang mengatakan bahwa:

"selama masa pandemic karakteristik penilaian kurikulum 13 tidak terpenuhi secara keseluruhan, namun saya mengusahakan agar pembelajaran tetap berjalan dengan baik serta materi pembelajaran tersampaikan dengan memberikan tugastugas, dan dari tugas-tugas tersebut saya harus dapat mengambil penilaian dari berbagai aspek seperti kognitif, afektif dan psikomotorik".

Dapat disimpulkan bahwa selama pembelajaran daring guru SDN Renged 3 menggunakan penilaian fortofolio yaitu dengan menganalisis tugas-tugas yang telah diberikan dari berbagai aspek kogitif, afektif dan psikomotorik.

b. Penilaian melalui tatap muka

Selain memberikan tugas pada peserta didik guru juga mengadakan pertemuan atau belajar secara tatap muka yaitu seminggu tiga kali dimana setiap pertemuan tatap muka guru akan membahas tugas-tugas yang sebelumya telah diberikan. Dengan diadakannya tatap muka akan membantu peserta didik dalam memahami materi pembelajaran dan juga dapat membantu guru juga dalam melakukan penilaian. 
Hasil penelitian ini diperkuat dengan ungkapan dari salah satu guru SDN Renged 3 yang mengatakan bahwa:

"saat diberlakukannya pembelajaran daring dan tidak ada tatap muka sama sekali guru hanya memberikan tugas-tugas, akan tetapi disaat sudah ada sedikit kelonggaran sekolah mengadakan pembelajaran tatap muka secara bergilir dan setiap kelas diberikan kesempaan untuk melakukan pembelajaran tatap muka seminggu dua kali".

C. Penilaian dilakukan dari kerajinan pesert didik

Selain dari penilaian melalui tugas dan pembelajaran tatap muka, penilaian juga dilihat dari kerajinan peserta didik dalam mengumpulkan tugas secara tepat waktu, kehadiran dan keaktifan peserta didik saat pembelajaran tatap muka.

Hasil penelitian ini diperkuat dengan ungkapan dari salah satu guru SDN
Renged 3 yang mengatakan bahwa:

"penilaian juga dapat dilihat dari seberapa rajin peserta didik dalam mengerjakan tugas yang diberikan, kehadiran dan keaktifan peserta didik saat melaksanakan pembelajaran tatap muka".

\section{Simpulan}

\begin{abstract}
Dapat disimpulkan bawa kesulitan guru dalam melaksanakan penilaian selama pandemic covid-19 yaitu keterbatasan pembelajaran tatap muka, melakukan penilaian afektif dan psikomotorik dan yang terakhir keterbatasan peserta didik dalam mengikuti pembelajaran daring (dalam jaringan)
\end{abstract}

Strategi yang dilakukan guru dalam melakukan penilaian yaitu dengan memberikan tugas-tugas melalui whatsapp grup dikarenakan tidak bisa melakukan pembelajaran melalui zoom meet, atau google meet dikarena kondisi peserta didik, akan tetapi disaat sudah ada sedikit kelonggaran sekolah mengadakan kegiatan pembelajaran secara tatap muka dengan bergilir. Hal tersebut 
dilakukan guru agar materi pembelajaran tetap tersampaikan dengan baik dan juga dapat membantu guru dalam melakukan penilaian hasil belajar. Kemudia guru juga menilai dari kerajinan peserta didik dalam mengerjakan tugas serta keaktifan dan kehadiran peserta didik disaat pembelajaran tatap muka.

\section{Daftar Pustaka}

Dwi, A. 2021. "Strategi Guru dalam $\begin{array}{ll}\text { Melaksanakan } & \text { Penilaian } \\ \text { Pembelajaran pada Masa }\end{array}$ Pandemi Covid-19 di Kelas Tinggi Sekola Dasar". Jurnal Fundadikdas (Fundamental Pendidikan Dasar), 4 (1).

Nuning, I. P. 2017. "Penggunaan Media Video Call dalam Teknologi komunikasi". Jurnal IImiah Dinamika Sosial, 1(2), 202224.

Rina, M. S., Nurhaida., \& Linda Vitoria. 2017. "Pelaksanaan Penilaian Hasil Belajar Siswa pada Sum Tema Hidup Rukun Dengan Teman Bermain di Kelas II SDN 14 Banda Aceh". Jurnal
IImiah Pendidikan Guru Sekolah Dasar, 2(1), 59-72.

Rose, W., \& Febrina, D. 2021. "Analisis Kesulitan Guru dalam Penggunaan Media Pembelajaran Online di Sekolah Dasar". Jurnal Pedagogi dan Pembelajaran, 4(2), 211-221.

Yantoroa. Suci H., \& Rahmada. 2021. "Strategi Penilaian Pembelajaran Matematika pada Masa Pandemi Covid-19 di Kelas Tinggi Sekola Dasar". Jurnal Fundadikdas (Fundamental Pendidikan Dasar), 4(1), 21-31. 